\title{
Low-Glycotoxin Diets and Spirulina may have Potential for Slowing the Growth and Spread of RAGE-expressing Cancers
}

Mark McCarty*

Catalytic Longevity, 7831 Rose Rush Dr, Apt. 316, Carlsbad, CA 92009, USA

"Corresponding author: Mark McCarty, Catalytic Longevity, 7831 Rose Rush Dr., Apt. 316, Carlsbad, CA 92009, USA, Tel: 760-216-7272; E-mail: markfmccarty@gmail.com

Received date: Feb 11, 2015; Accepted date: Mar 16, 2015; Published date: Mar 23, 2015

Copyright: ( 2015 McCarty M. This is an open-access article distributed under the terms of the Creative Commons Attribution License, which permits unrestricted use, distribution, and reproduction in any medium, provided the original author and source are credited.

\begin{abstract}
A number of recent studies indicate that many cancers express receptors for advanced glycation end products (RAGEs), and that stimulation of these receptors make these cancers more invasive and, in some cases, boosts their proliferation. In some of these cancers, autocrine production of protein agonists for RAGE (HMGB1, S1100A) promotes their spread; the typically aggressive growth of cancers in diabetics may reflect activation of RAGE by endogenously produced advanced glycation end products (AGEs). But RAGE can also be activated by dietary "glycotoxins" - compounds produced by Maillard reactions in highly heated foods that are structurally and functionally similar to AGEs produced in diabetics. In rodents, dietary glycotoxins promote oxidative stress and pathologies linked to oxidative stress, presumably via RAGE activation. These considerations suggest that lowglycotoxin diets may have potential for slowing the spread of certain cancers expressing RAGE, a proposition that can readily be tested in rodent tumor models. Guidelines for achieving such diets have been published; low-fat foods of plant origin are typically low in glycotoxins, and the glycotoxin content of animal products and fatty plant products can be minimized by cooking at low heat (e.g. boiling, steaming). It may also be feasible to suppress the downstream signaling of RAGE in cancers by inhibiting the activity of NADPH oxidase, which appears to be the chief source of the oxidative stress triggered by RAGE; a role for NADPH oxidase in the aggressive growth of many cancers has been established. By mimicking the physiological antioxidant role of free bilirubin, the phycocyanobilin richly supplied by spirulina has the potential to down-regulate NADPH oxidase activity, and thereby impede RAGE signaling.
\end{abstract}

Keywords: Advanced glycation end products; RAGE; Glycotoxins; Cancer; Diet; Cooking; NADPH oxidase; Spirulina

\section{A Role for RAGE Signaling in Cancer Aggressiveness}

Recent studies have demonstrated that a wide range of cancers can express RAGE receptors (receptors for advanced glycation products), and that stimulation of these receptors renders the cancer more aggressive - more invasive and, in some cases, more proliferative [1-13]. Many of these cancers produce endogenous proteins - HMGB1 or S100A8 for example - that function to stimulate these receptors; hence, an autocrine loop can promote RAGE activation in these cancers $[1,2,8,11,12,14]$. In such cancers, knock-down of RAGE expression, or administration of a soluble RAGE receptor (which opposes RAGE signaling by acting as a decoy) or of a RAGE antagonist, can slow cancer growth and spread $[1,5,7,9,10]$. When chemotherapy kills cancer cells by necrosis, the resultant release of HMGB1 into the circulation may stimulate the growth of surviving cancer cells which express RAGE receptors [15].

\section{Dietary Glycotoxin Content may Modulate the Growth of Rage-Expressing Cancers}

But it stands to reason that advanced glycation end-products (AGEs) of endogenous origin, or absorbed from the diet, should also promote the aggressiveness of such cancers. Indeed, as has recently been suggested, this may help to explain why cancers tend to progress more rapidly in diabetic patients, and why poorer diabetic control (high $\mathrm{HbAlc}$ ) is associated with poorer prognosis [13,16-22]. With respect to dietary impacts on RAGE activity, studies by Vlassara and colleagues have established that cooked foods often contain absorbable "glycotoxins" capable of activating RAGE [23-25]. These compounds typically arise from heat-catalyzed Maillard reactions which are initiated when an amine group, usually from protein or nucleic acid, forms a Schiff base with an aldehyde or ketone from a metabolite of a sugar or fatty acid. When a fatty acid metabolite is involved in this reaction - as when 4-hydroxynonenal reacts with an amine - the resulting product is called an "advanced lipoxidation end product" [26]. The term "glycotoxin" is a bit of a misnomer, as the highest content of these toxins is typically found in low-carbohydrate foods that are high in both fat and protein, and subjected to high heat - most notably, cooked flesh foods [24]. Remarkably, cooked diets rich in absorbable glycotoxins have been shown to promote oxidative stress, renal damage, atherosclerosis, metabolic syndrome, fatty liver disease, and cognitive dysfunction in rodents, to delay wound healing, and to shorten lifespan [27-32]. Clinically, ingestion of glycotoxin-rich diets boosts the level of AGEs measured in plasma, increases C-reactive protein, and impairs endothelial function [25,33,34]. In one provocative study, type 2 diabetics advised to decrease the glycotoxin content of their usual diet by using lower heat in food preparation for a 4 month period, achieved improvements in insulin sensitivity and markers of inflammation and oxidative stress [35]. Epidemiologically, habitual consumption of high-glycotoxin diets has been linked to increased risk for early cognitive decline, Alzheimer's disease, and pancreatic cancer [36-39]. 
In light of these considerations, it is reasonable to predict that diets high in glycotoxins will tend to boost the growth and spread of cancers that express functional RAGE receptors. Conversely, low-glycotoxin diets would seem likely to slow the spread of such cancers to some degree. In RAGE-expressing cancers that also make their own RAGE agonists, a low-glycotoxin diet will evidently only partially dampen RAGE signaling, but this benefit still might be worthwhile in some cases. This hypothesis could be readily tested in nude mice bearing RAGE-expressing tumors; the impact of high-glycotoxin vs. lowglycotoxin diets on the growth and spread of such cancers could be assessed.

Plant-based raw food diets would be expected to be exceptionally low in glycotoxins. It is curious to note that such diets have been recommended for cancer control by various "alternative" practitioners whose views have usually been accorded little respect by orthodox medical scientists [40]. Of course, the dubious rationales typically given for use of raw food diets in cancer treatment (live enzymes!) tend to invite ridicule. Such diets also might be expected to slow the growth of some cancers by down-regulating systemic levels of free IGF-I and promoting good insulin sensitivity $[41,42]$.

However, a low-glycotoxin diet need not be composed solely of raw foods. Uribarri and collegues have measured the glycotoxin content of a wide range of common foods, prepared in various ways, and have summarized their findings in a monograph [24]. By and large, low-fat plant-derived foods are low in glycotoxins even if cooked. The highest glycotoxin content is typically seen in foods high in both fat and protein - meat, poultry, fish, cheese, nuts and nut butters, tofu - which have been subjected to high heat during preparation. When cooking such foods, their glycotoxin content can be mitigated to some degree by the use of lower-temperature cooking methods (boiling, poaching, stewing, steaming), shorter cooking times, and the addition of lemon juice or vinegar [24]. So the glycotoxin content of almost any characteristic diet can be reduced by appropriate modification of cooking techniques. Minimal glycotoxin content will be found in lowfat plant-based diets that are raw or cooked with moderate heat.

\section{Alternate Strategies for Impeding Rage Signaling in Cancer - Focus on Spirulina}

As noted, low-glycotoxin diets could not be expected to abrogate RAGE signaling in cancers which make their own RAGE agonist proteins. Evidently, agents which either impede the interaction of RAGE receptors with their agonists, or which intervene downstream in RAGE signaling, could be useful in the control of RAGE-expressing cancers. In mice bearing RAGE-expressing human tumors, injection of soluble RAGE receptors, or of modified forms of the RAGE-agonist protein S100P which block RAGE activation, slowed cancer growth and metastasis $[1,7]$.

With respect to intervening in RAGE signaling, a number of studies examining a range of cells types have concluded that activation of $\mathrm{NADPH}$ complexes is the chief source of the oxidative stress induced by RAGE activation; moreover, some of these studies demonstrate that inhibition of NADPH oxidase abrogates other key downstream effects of RAGE signaling [43-57]. The role of NADPH oxidase in RAGE signaling in cancer cells has so far received little study, although RAGE activation has been shown to potently activate NADPH oxidase in a human neuroblastoma cell line [58]. If indeed NADPH oxidase is a key mediator of the impact of RAGE signaling on cancer aggressiveness, then safe strategies for down-regulating $\mathrm{NADPH}$ oxidase activation may prove useful for reducing the aggressiveness of cancers expressing RAGE. It should be noted that many cancers express constitutive NADPH oxidase activity, and that the oxidants generated by this complex often promote cancer proliferation and invasiveness, in part by reversibly inhibiting tyrosine phosphatases which oppose growth factor signaling; up-regulation of NF-kappaB and AP-1 signaling may also play a role in this regard [59-63].

In this regard, free bilirubin functions physiologically to inhibit certain NADPH [64-67]. Moreover, the biliverdin homolog phycocyanobilin, a major constituent of cyanobacteria such as the food spirulina, can be reduced intracellularly to the bilirubin homolog phycocyanorubin, which mimics bilirubin's inhibitory impact on NADPH oxidase activity [68-70]. This effect seems likely to explain the versatile anti-inflammatory and antioxidant effects of orally administered spirulina or phycocyanin (the spirulina protein which contains phycocyanobilin as a chromophore) observed in rodent studies $[68,71]$. Although the effects of oral administration of spirulina or of phycocyanobilin on cancer growth have so far received little research attention, one recent study found that dietary spirulina slowed the growth of a human pancreatic adenocarcinoma implanted in nude mice by about $60 \%$ [72]. The impact of phycocyanobilin or its homolog biliverdin on RAGE signaling in cancer cells lines could readily be studied.

If indeed bilirubin and phycocyanobilin can suppress RAGE signaling, this will likely have implications for the prevention of diabetic complications, in which RAGE is believed to play a key mediating role [73]. In this regard, there is epidemiological evidence that diabetics who also have Gilbert syndrome - a genetic variant in which plasma levels of free bilirubin are constitutively elevated - are at greatly lower risk for developing diabetic complications (nephropathy, retinopathy, and coronary disease) [74]. Moreover, rodent studies demonstrate that NADPH oxidase overactivity is a key mediator of such complications [75-77]. And oral administration of either biliverdin or phycocyanobilin has been reported to prevent nephrosclerosis in diabetic mice [78,79]. Hence, examining the impact of these compounds on RAGE signaling should be a high priority.

\section{References}

1. Taguchi A, Blood DC, del Toro G, Canet A, Lee DC, et al. (2000) Blockade of RAGE-amphoterin signalling suppresses tumour growth and metastases. Nature 405: 354-360.

2. Fuentes MK, Nigavekar SS, Arumugam T, Logsdon CD, Schmidt AM, et al. (2007) RAGE activation by S100P in colon cancer stimulates growth, migration, and cell signaling pathways. Dis Colon Rectum 50: 1230-1240.

3. Takino J, Yamagishi S, Takeuchi M (2010) Cancer malignancy is enhanced by glyceraldehyde-derived advanced glycation end-products. J Oncol 2010: 739852.

4. DiNorcia J, Moroziewicz DN, Ippagunta N, Lee MK, Foster M, et al. (2010) RAGE signaling significantly impacts tumorigenesis and hepatic tumor growth in murine models of colorectal carcinoma. J Gastrointest Surg 14: 1680-1690.

5. Elangovan I, Thirugnanam S, Chen A, Zheng G, Bosland MC, et al (2012) Targeting receptor for advanced glycation end products (RAGE) expression induces apoptosis and inhibits prostate tumor growth. Biochem Biophys Res Commun 417: 1133-1138.

6. Takino J, Yamagishi S, Takeuchi M (2012) Glycer-AGEs-RAGE signaling enhances the angiogenic potential of hepatocellular carcinoma by upregulating VEGF expression. World J Gastroenterol 18: 1781-1788.

7. Arumugam T, Ramachandran V, Gomez SB, Schmidt AM, Logsdon CD (2012) S100P-derived RAGE antagonistic peptide reduces tumor growth and metastasis. Clin Cancer Res 18: 4356-4364. 
8. Kang R, Tang D, Schapiro NE, Loux T, Livesey KM, et al. (2014) The HMGB1/RAGE inflammatory pathway promotes pancreatic tumor growth by regulating mitochondrial bioenergetics. Oncogene 33: 567-577.

9. Radia AM, Yaser AM, Ma X (2013) Specific siRNA Targeting Receptor for Advanced Glycation End Products (RAGE) Decreases Proliferation in Human Breast Cancer Cell Lines. Int J Mol Sci 14: 7959-7978.

10. Xu XC, Abuduhadeer X, Zhang WB, Li T, Gao H, et al. (2013) Knockdown of RAGE inhibits growth and invasion of gastric cancer cells. Eur J Histochem 57: e36.

11. Chen RC, Yi PP, Zhou RR, Xiao MF, Huang ZB, et al. (2014) The role of HMGB1-RAGE axis in migration and invasion of hepatocellular carcinoma cell lines. Mol Cell Biochem 390: 271-280.

12. Reeb AN, Li W, Sewell W, Marlow LA, Tun HW, et al. (2015) S100A8 is a Novel Therapeutic Target for Anaplastic Thyroid Carcinoma. J Clin Endocrinol Metab 100: E232-242.

13. Chen H, Wu L, Li Y, Meng J, Lin N, et al. (2014) Advanced glycation end products increase carbohydrate responsive element binding protein expression and promote cancer cell proliferation. Mol Cell Endocrino 395: 69-78.

14. Logsdon CD, Fuentes MK, Huang EH, Arumugam T (2007) RAGE and RAGE ligands in cancer. Curr Mol Med 7: 777-789.

15. Luo Y, Chihara Y, Fujimoto K, Sasahira T, Kuwada M, et al. (2013) High mobility group box 1 released from necrotic cells enhances regrowth and metastasis of cancer cells that have survived chemotherapy. Eur J Cancer 49: 741-751.

16. Siddiqui AA, Spechler SJ, Huerta S, Dredar S, Little BB, et al. (2008) Elevated $\mathrm{HbAlc}$ is an independent predictor of aggressive clinical behavior in patients with colorectal cancer: a case-control study. Dig Dis Sci 53: 2486-2494.

17. Ozbek E, Otunctemur A, Dursun M, Sahin S, Besiroglu H, et al. (2014) Diabetes mellitus and HbAlc levels associated with high grade prostate cancer. Asian Pac J Cancer Prev 15: 2555-2558.

18. Cheon YK, Koo JK, Lee YS, Lee TY, Shim CS (2014) Elevated hemoglobin Alc levels are associated with worse survival in advanced pancreatic cancer patients with diabetes. Gut Liver 8: 205-214.

19. Kondo S, Kondo M, Kondo A (2013) Glycemia control using A1C level in terminal cancer patients with preexisting type 2 diabetes. J Palliat Med 16: 790-793.

20. Kim HS, Presti JC Jr, Aronson WJ, Terris MK, Kane CJ, et al. (2010) Glycemic control and prostate cancer progression: results from the SEARCH database. Prostate 70: 1540-1546.

21. Erickson K, Patterson RE, Flatt SW, Natarajan L, Parker BA, et al. (2011) Clinically defined type 2 diabetes mellitus and prognosis in early-stage breast cancer. J Clin Oncol 29: 54-60.

22. Hong SK, Lee ST, Kim SS, Min KE, Byun SS, et al. (2009) Significance of preoperative $\mathrm{HbAlc}$ level in patients with diabetes mellitus and clinically localized prostate cancer. Prostate 69: 820-826.

23. Koschinsky T, He CJ, Mitsuhashi T, Bucala R, Liu C, et al. (1997) Orally absorbed reactive glycation products (glycotoxins): an environmental risk factor in diabetic nephropathy. Proc Natl Acad Sci U S A 94: 6474-6479.

24. Uribarri J, Woodruff S, Goodman S, Cai W, Chen X, et al. (2010) Advanced glycation end products in foods and a practical guide to their reduction in the diet. J Am Diet Assoc 110: 911-916.

25. Uribarri J, Cai W, Sandu O, Peppa M, Goldberg T, et al. (2005) Dietderived advanced glycation end products are major contributors to the body's AGE pool and induce inflammation in healthy subjects. Ann N Y Acad Sci 1043: 461-466.

26. Miyata T, Kurokawa K, Van Ypersele De Strihou C (2000) Advanced glycation and lipoxidation end products: role of reactive carbonyl compounds generated during carbohydrate and lipid metabolism. J Am Soc Nephrol 11: 1744-1752.
27. Lin RY, Choudhury RP, Cai W, Lu M, Fallon JT, et al. (2003) Dietary glycotoxins promote diabetic atherosclerosis in apolipoprotein Edeficient mice. Atherosclerosis 168: 213-220.

28. Vlassara H, Striker G (2007) Glycotoxins in the diet promote diabetes and diabetic complications. Curr Diab Rep 7: 235-241.

29. Cai W, He JC, Zhu L, Chen X, Zheng F, et al. (2008) Oral glycotoxins determine the effects of calorie restriction on oxidant stress, age-related diseases, and lifespan. Am J Pathol 173: 327-336.

30. Cai W, Uribarri J, Zhu L, Chen X, Swamy S, et al. (2014) Oral glycotoxins are a modifiable cause of dementia and the metabolic syndrome in mice and humans. Proc Natl Acad Sci U S A 111: 4940-4945.

31. Leung C, Herath CB, Jia Z, Goodwin M, Mak KY, et al. (2014) Dietary glycotoxins exacerbate progression of experimental fatty liver disease. J Hepatol 60: 832-838.

32. Peppa M, Brem H, Ehrlich P, Zhang JG, Cai W, et al. (2003) Adverse effects of dietary glycotoxins on wound healing in genetically diabetic mice. Diabetes 52: 2805-2813.

33. Uribarri J, Peppa M, Cai W, Goldberg T, Lu M, et al. (2003) Restriction of dietary glycotoxins reduces excessive advanced glycation end products in renal failure patients. J Am Soc Nephrol 14: 728-731.

34. Uribarri J, Stirban A, Sander D, Cai W, Negrean M, et al. (2007) Single oral challenge by advanced glycation end products acutely impairs endothelial function in diabetic and nondiabetic subjects. Diabetes Care 30: $2579-2582$.

35. Uribarri J, Cai W, Ramdas M, Goodman S, Pyzik R, et al. (2011) Restriction of advanced glycation end products improves insulin resistance in human type 2 diabetes: potential role of AGER1 and SIRT1. Diabetes Care 34: 1610-1616.

36. Beeri MS, Moshier E, Schmeidler J, Godbold J, Uribarri J, et al. (2011) Serum concentration of an inflammatory glycotoxin, methylglyoxal, is associated with increased cognitive decline in elderly individuals. Mech Ageing Dev 132: 583-587.

37. West RK, Moshier E, Lubitz I, Schmeidler J, Godbold J, et al. (2014) Dietary advanced glycation end products are associated with decline in memory in young elderly. Mech Ageing Dev 140: 10-12.

38. Perrone L, Grant WB (2015) Observational and Ecological Studies of Dietary Advanced Glycation End Products in National Diets and Alzheimer's Disease Incidence and Prevalence. J Alzheimers Dis .

39. Jiao L, Stolzenberg-Solomon R, Zimmerman TP, Duan Z, Chen L, et al. (2015) Dietary consumption of advanced glycation end products and pancreatic cancer in the prospective NIH-AARP Diet and Health Study. Am J Clin Nutr 101: 126-134.

40. Rossing N (1988) [Raw food against cancer. A report from a study done by the Society for Alternative Medicine]. Ugeskr Laeger 150: 613-615.

41. Fontana L, Weiss EP, Villareal DT, Klein S, Holloszy JO (2008) Longterm effects of calorie or protein restriction on serum IGF-1 and IGFBP-3 concentration in humans. Aging Cell 7: 681-687.

42. Fontana L, Meyer TE, Klein S, Holloszy JO (2007) Long-term low-calorie low-protein vegan diet and endurance exercise are associated with low cardiometabolic risk. Rejuvenation Res 10: 225-234.

43. Wautier MP, Chappey O, Corda S, Stern DM, Schmidt AM, et al. (2001) Activation of NADPH oxidase by AGE links oxidant stress to altered gene expression via RAGE. Am J Physiol Endocrinol Metab 280: E685-694.

44. Zhang L, Zalewski A, Liu Y, Mazurek T, Cowan S, et al. (2003) Diabetesinduced oxidative stress and low-grade inflammation in porcine coronary arteries. Circulation 108: 472-478.

45. Cai W, Torreggiani M, Zhu L, Chen X, He JC, et al. (2010) AGER1 regulates endothelial cell NADPH oxidase-dependent oxidant stress via PKC-delta: implications for vascular disease. Am J Physiol Cell Physiol 298: C624-634.

46. Basta G, Lazzerini G, Del TS, Ratto GM, Schmidt AM, et al. (2005) At least 2 distinct pathways generating reactive oxygen species mediate vascular cell adhesion molecule-1 induction by advanced glycation end products. Arterioscler Thromb Vasc Biol 25: 1401-1407. 
47. Higai K, Shimamura A, Matsumoto K (2006) Amadori-modified glycated albumin predominantly induces E-selectin expression on human umbilical vein endothelial cells through NADPH oxidase activation. Clin Chim Acta 367: 137-143.

48. Guo J, Ananthakrishnan R, Qu W, Lu Y, Reiniger N, et al. (2008) RAGE mediates podocyte injury in adriamycin-induced glomerulosclerosis. J Am Soc Nephrol 19: 961-972.

49. Guo ZJ, Niu HX, Hou FF, Zhang L, Fu N, et al. (2008) Advanced oxidation protein products activate vascular endothelial cells via a RAGE-mediated signaling pathway. Antioxid Redox Signal 10: 1699-1712.

50. Warboys CM, Toh HB, Fraser PA (2009) Role of NADPH oxidase in retinal microvascular permeability increase by RAGE activation. Invest Ophthalmol Vis Sci 50: 1319-1328.

51. Guimarães EL, Empsen C, Geerts A, van Grunsven LA (2010) Advanced glycation end products induce production of reactive oxygen species via the activation of NADPH oxidase in murine hepatic stellate cells. J Hepatol 52: 389-397.

52. Lee BW, Chae HY, Kwon SJ, Park SY, Ihm J, et al. (2010) RAGE ligands induce apoptotic cell death of pancreatic $\hat{\mathrm{I}}^{2}$-cells via oxidative stress. Int J Mol Med 26: 813-818.

53. Maeda S, Matsui T, Takeuchi M, Yamagishi S (2011) Pigment epithelium-derived factor (PEDF) blocks advanced glycation end products (AGEs)-RAGE-induced suppression of adiponectin mRNA level in adipocytes by inhibiting NADPH oxidase-mediated oxidative stress generation. Int J Cardiol 3: 408-410.

54. Yin QQ, Dong CF, Dong SQ, Dong XL, Hong Y, et al. (2012) AGEs induce cell death via oxidative and endoplasmic reticulum stresses in both human SH-SY5Y neuroblastoma cells and rat cortical neurons. Cell Mol Neurobiol 32: 1299-1309.

55. Wei Q, Ren X, Jiang Y, Jin H, Liu N, et al. (2013) Advanced glycation end products accelerate rat vascular calcification through RAGE/oxidative stress. BMC Cardiovasc Disord 13: 13.

56. Shi L, Chen H, Yu X, Wu X (2013) Advanced glycation end products delay corneal epithelial wound healing through reactive oxygen species generation. Mol Cell Biochem 383: 253-259.

57. Daffu G, del Pozo CH, O'Shea KM, Ananthakrishnan R, Ramasamy R, et al. (2013) Radical roles for RAGE in the pathogenesis of oxidative stress in cardiovascular diseases and beyond. Int J Mol Sci 14: 19891-19910.

58. Yin QQ, Dong CF, Dong SQ, Dong XL, Hong Y, et al. (2012) AGEs induce cell death via oxidative and endoplasmic reticulum stresses in both human SH-SY5Y neuroblastoma cells and rat cortical neurons. Cell Mol Neurobiol 32: 1299-1309.

59. McCarty MF, Barroso-Aranda J, Contreras F (2007) A two-phase strategy for treatment of oxidant-dependent cancers. Med Hypotheses 69: 489-496.

60. Chan EC, Jiang F, Peshavariya HM, Dusting GJ (2009) Regulation of cell proliferation by NADPH oxidase-mediated signaling: potential roles in tissue repair, regenerative medicine and tissue engineering. Pharmacol Ther 122: 97-108.

61. Lee JK, Edderkaoui M, Truong P, Ohno I, Jang KT, et al. (2007) NADPH oxidase promotes pancreatic cancer cell survival via inhibiting JAK2 dephosphorylation by tyrosine phosphatases. Gastroenterology 133: 1637-1648.

62. Kang SW, Lee S, Lee EK (2015) ROS and energy metabolism in cancer cells: alliance for fast growth. Arch Pharm Res 38: 338-345.
63. Weyemi U, Redon CE, Parekh PR, Dupuy C, Bonner WM (2013) NADPH Oxidases NOXs and DUOXs as putative targets for cancer therapy. Anticancer Agents Med Chem 13: 502-514.

64. Lanone S, Bloc S, Foresti R, Almolki A, Taillé C, et al. (2005) Bilirubin decreases nos 2 expression via inhibition of $\mathrm{NAD}(\mathrm{P}) \mathrm{H}$ oxidase: implications for protection against endotoxic shock in rats. FASEB J 19: 1890-1892.

65. Matsumoto $\mathrm{H}$, Ishikawa $\mathrm{K}$, Itabe $\mathrm{H}$, Maruyama $\mathrm{Y}$ (2006) Carbon monoxide and bilirubin from heme oxygenase-1 suppresses reactive oxygen species generation and plasminogen activator inhibitor-1 induction. Mol Cell Biochem 291: 21-28.

66. Jiang F, Roberts SJ, Datla Sr, Dusting GJ (2006) NO modulates NADPH oxidase function via heme oxygenase-1 in human endothelial cells. Hypertension 48: 950-957.

67. Datla SR, Dusting GJ, Mori TA, Taylor CJ, Croft KD, et al. (2007) Induction of heme oxygenase-1 in vivo suppresses NADPH oxidase derived oxidative stress. Hypertension 50: 636-642.

68. McCarty MF1 (2007) Clinical potential of Spirulina as a source of phycocyanobilin. J Med Food 10: 566-570.

69. Terry MJ, Maines MD, Lagarias JC (1993) Inactivation of phytochromeand phycobiliprotein-chromophore precursors by rat liver biliverdin reductase. J Biol Chem 268: 26099-26106.

70. Zheng J, Inoguchi T, Sasaki S, Maeda Y, McCarty MF, et al. (2013) Phycocyanin and phycocyanobilin from Spirulina platensis protect against diabetic nephropathy by inhibiting oxidative stress. Am J Physiol Regul Integr Comp Physiol 304: R110-120.

71. Romay Ch, González R, Ledón N, Remirez D, Rimbau V (2003) Cphycocyanin: a biliprotein with antioxidant, anti-inflammatory and neuroprotective effects. Curr Protein Pept Sci 4: 207-216.

72. Koníčková $R$, Vaňková $K$, Vaníková J, Váňová $K$, Muchová $L$, et al (2014) Anti-cancer effects of blue-green alga Spirulina platensis, a natural source of bilirubin-like tetrapyrrolic compounds. Ann Hepatol 13: 273-283.

73. Yamamoto Y, Yamamoto H (2012) Controlling the receptor for advanced glycation end-products to conquer diabetic vascular complications. J Diabetes Investig 3: 107-114.

74. Inoguchi T, Sasaki S, Kobayashi K, Takayanagi R, Yamada T (2007) Relationship between Gilbert syndrome and prevalence of vascular complications in patients with diabetes. JAMA 298: 1398-1400.

75. Inoguchi $\mathrm{T}$, Nawata $\mathrm{H}(2005) \mathrm{NAD}(\mathrm{P}) \mathrm{H}$ oxidase activation: a potential target mechanism for diabetic vascular complications, progressive betacell dysfunction and metabolic syndrome. Curr Drug Targets 6: 495-501.

76. Kowluru A, Kowluru RA (2014) Phagocyte-like NADPH oxidase [Nox2] in cellular dysfunction in models of glucolipotoxicity and diabetes. Biochem Pharmacol 88: 275-283.

77. Gray SP, Jandeleit-Dahm K (2014) The pathobiology of diabetic vascular complications--cardiovascular and kidney disease. J Mol Med (Berl) 92: 441-452.

78. Fujii M, Inoguchi T, Sasaki S, Maeda Y, Zheng J, et al. (2010) Bilirubin and biliverdin protect rodents against diabetic nephropathy by downregulating NAD(P)H oxidase. Kidney Int 78: 905-919.

79. Zheng J, Inoguchi T, Sasaki S, Maeda Y, McCarty MF, et al. (2013) Phycocyanin and phycocyanobilin from Spirulina platensis protect against diabetic nephropathy by inhibiting oxidative stress. Am J Physiol Regul Integr Comp Physiol 304: R110-120. 